\title{
Health and illness are social phenomena
}

Sir,

Health and illness depend on everyday life and more broadly on the life of the society, i.e., they depend on the manifestations of both micro and macro levels. ${ }^{[1]}$ Many researchers have referred to economic hardships caused by changes as factors aggravating people's physical and mental state. ${ }^{[2]}$ It would also be appropriate to recall here the thesis of McKeown: Aside from medical research aiming at improving the health of the population, is it not more important to make an effort to increase the social, political, and economic resources determining people's health. ${ }^{\text {[3] }}$

In Estonia, as well as in other East-European countries, the transition from centrally planned economy to market 
economy caused changes in socio-economic life. Reforms also gave rise to negative phenomena, which primarily constituted new sources of stress. Discussing the influence of critical times on the health of Estonian people, Kutsar $(1995)^{[4]}$ has shown that one of the factors increasing stress may be the contact with new phenomena, such as the market economy, unemployment, competition, and poverty, and if people are not able to adjust to the rapid changes, it may result in passivity, frustration, and dissatisfaction.

Based on the assessments of their economic situation given by the respondents, Estonian researchers have differentiated between two groups of respondents-the "losers" and the "winners" of the transition period. The "winners" have better than average health $(55 \%$ of them assess their health as good or very good while only $25 \%$ of the "losers" give the same assessment to their health) and they take better care of themselves (36\% of the "winners" and only $17 \%$ of the "losers" do physical exercise at least once a week). ${ }^{[5]}$

Researchers have compared the differences between the coping levels of people of different countries. Surveys carried out in Helsinki and Moscow in 1991 demonstrated that socio-economic changes that had taken place in the Soviet Union had caused serious adjustment problems to the citizens of Moscow. People felt that they were not coping with their life, were not able to achieve their goals, they thought that life was pointless and there was no hope for the future. In Helsinki, estrangement was more frequent among people who were losing their chances in the society - the elderly and the less educated. Among citizens of Moscow, estrangement, frustration, and pessimism were much more widely spread. ${ }^{[6]}$

In a study carried out between 1994 and 1996, Czech researchers studied how socio-economic changes in the society increased the stress levels of family members and influenced their mutual relationships. They showed that economic pressure made the spouses, both men and women more easily irritable. An increase in stress caused negative behavioral problems (e.g., alcohol consumption and physical violence), instability of the family, divorce, and depression. ${ }^{[7]}$ Many other researchers have also claimed that changes taking place in the society influence family life and burden all family members. Studies of Californian families during the Great Depression and the crisis of the Midwest farm confirmed that unemployment and loss of or decrease in a family member's income, especially if this is the husband, are often accompanied by the state of irritation and violent behavior. ${ }^{[8]}$
As discussed above, many researchers believe that socioeconomic changes in the society are reflected in the mental and physical health of the population. This is also confirmed by the results of the population surveys "Estonia 2003" and "Estonia 2008." According to the surveys, the Estonian population's satisfaction with various areas of life, including health, has significantly improved over the decade. In 1993, Estonians' satisfaction with their health was at its low (average grade on a five-point scale was 3.10). It may be stated that after surviving the shock therapy accompanying the transition to market economy, the situation has somewhat stabilized and people are beginning to regain their balance (grading their health with an average 3.60 in 2008). ${ }^{[9]}$

The principles of influencing the health of Estonian people have changed. Anu Kasmel (2005) ${ }^{[10]}$ emphasizes that the cause of the "sick society" lies in the incorrect interpretation of health: When speaking about the health of the population, illnesses and their treatment are generally emphasized, creating the impression that the only key to solving the population's health problems is medical assistance and the health insurance system. Other authors have similarly shown that health care systems of many countries exaggerate the attention to taking care of sick people while much better results could be achieved by preventing illnesses and promoting health. ${ }^{[11,12]}$

Some of the responsibility for being healthy definitely falls on the person himself or herself: Whether he or she attempts to follow a healthy lifestyle, behaves safely in the traffic, curbs alcohol consumption and smoking, improves eating habits. The state, though, is responsible for creating the necessary conditions for people to lead a healthy life.

Today, positive steps in that direction have been taken in Estonia: A National Health Plan for 2008-2020 has been adopted. Jobs of health promoters have been created in local governments and since 2007, respective Bachelor's and Master's programs have been taught at Estonian universities. Studies of the health behavior of the adult population have been conducted every two years since 1990.

In the recent years, many different campaigns have been carried out: Move to be healthy, healthy food, smokefree classes, promotion of HIV testing, information about the prevention of blood-transmitted diseases (HIV, hepatitis) is available on the Internet. Legislation is actively being updated (the Tobacco Law was 
introduced; restrictions on alcohol sale have come into effect).

Although people are able to do quite a lot to improve their health, the health of the population can only improve in the future when the state, the whole society invests in it. Since the resources allocated to health care continue to be insufficient, researchers are recommending the states to devote a significantly larger share of its national income to health care and to public health and prevention. ${ }^{[11]}$ They also emphasize the importance of partnership: "Partnerships are key to tackling health challenges. Many partners need to be involved. This includes, for example, governments, the health service, food and catering industry, and the fitness industries as well as transport planners in local government." ${ }^{\text {[11,12] }}$

\author{
Virve-Ines Laidmäe \\ Researcher, Institute of Social Work, Tallinn University, Estonia
}

Corresponding Author: Mrs. Virve-Ines Laidmäe, Researcher, Tallinn University, Estonia. E-mail:Virve.laidmae@gmail.com

\section{REFERENCES}

1. Bury M. Health and IIIness in a Changing Society. London University, London:1997. p. 246.

2. Habicht J, Kunst AE. Social inequalities in health care services utilisation after eight years of health care reforms: A crosssectional study of Estonia, 1999. Soc Sci Med 2005;60:777-87.

3. Link BG, Phelan JC. McKeown and idea that social conditions are fundamental causes of disease. Am J Public Health 2002;92:730-2.

4. Kutsar D. Social change and stress in Estonia. Scand J Soc Welf 1995;4:94-107.

5. Narusk A, Hansson L. Transition to the market economy: Estonian families and their coping strategies. Trondheim: Norwegian University of Science and Technology, 1996.

6. Palosuo H, Zhuravleva I, Uutela A, Lakomova N, Shilova L. Perceived health, health-related habits and attitudes in Helsinki and Moscow: A comparative study of adult populations in 1991. Kansanterveyslaitoksen Julkaisuja, A10. Helsinki: National Public Health Institute, 1995.

7. Hraba J, Lorenz FO, Pechačová Z. Family stress during the Czech Transformation. J Marriage Fam 2000;62:520-31.

8. Lorenz FO, Conger RD, Montague R. Doing worse and feeling worse: Psychological consequences of economic hardship. In: Conger RD, Elder GH Jr., editors. Troubled Times: Adapting to Change in Rural America. New York: Aldine; 1994. p. 167-86.

9. Laidmäe VI. Tervisehinnangud ja tervisekäitumine (Health and health behavior). Hansson L, editor. Work Home and Leisure: Everyday life in Estonia 1985-2008. Tallinn University,Institute of International and social studies) Tallinn: TLÜ; 2009. p. 115-49.

10. Kasmel A. Rahvastiku tervis - reaalsus ja võimalused (Health of the population - reality and opportunities). Raska E, Raitviir T, editors. Eesti edu hind: Eesti sotsiaalne julgeolek ja rahva turvalisus (The price of Estonian success: Social security and people's safety in Estonia) Tallinn: Estonia Entsüklopeediakirjastus(Encyclopaedia Publishers; 2005. p. 95-110.

11. Brouwer W, Van Exel J, Van Baal P, Polder J. Economics and public health: Engaged to be happily married! Eur J Public Health 2007; 17:122-3.

12. Donaldson SL. The future of public health in Europe. Eur J Public Health 2006;16:459-61.

\begin{tabular}{|l|l|}
\hline \multicolumn{2}{|c|}{ Access this article online } \\
\hline Quick Response Code: & Website: \\
\hline & www.joshd.net \\
\hline & \\
\hline
\end{tabular}

